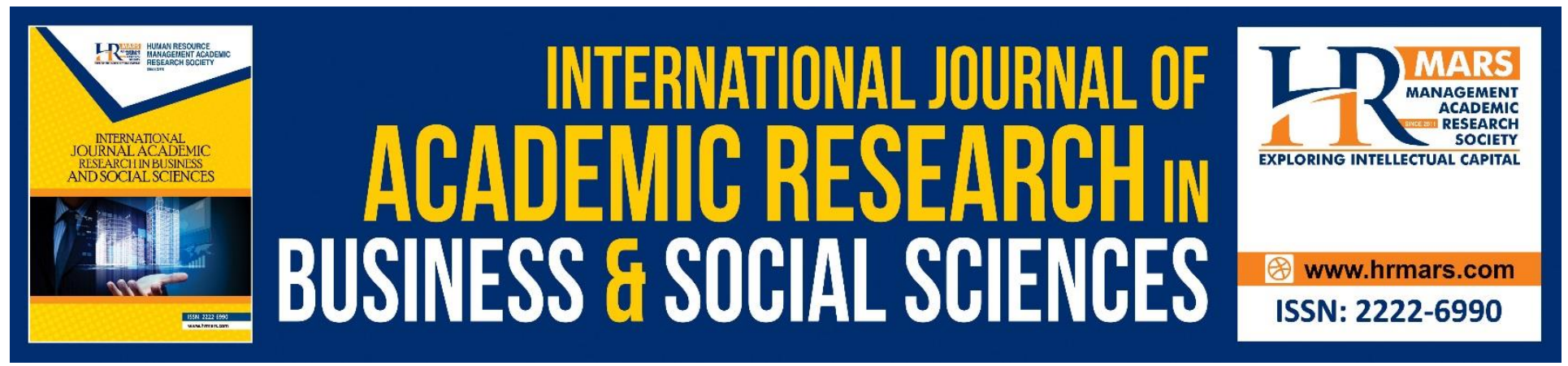

\title{
Coggle: SWOT Analysis in Lifelong Learning Education Using Online Collaborative Mind-Mapping
}

Nurul Aisyah Kamrozzaman, Jamaludin Badusah, Wan Muna Ruzanna Wan Mohammad

To Link this Article: http://dx.doi.org/10.6007/IJARBSS/v8-i12/5431

DOI: $10.6007 /$ IJARBSS/v8-i12/5431

Received: 13 Nov 2018, Revised: 26 Dec 2018, Accepted: 30 Dec 2018

Published Online: 04 Dec 2018

In-Text Citation: (Kamrozzaman, Badusah, \& Mohammad, 2018)

To Cite this Article: Kamrozzaman, N. A., Badusah, J., \& Mohammad, W. M. R. W. (2018). Coggle: SWOT Analysis in Lifelong Learning Education Using Online Collaborative Mind-Mapping. International Journal of Academic Research in Business and Social Sciences, 8(12), 2195-2206.

Copyright: (C) 2018 The Author(s)

Published by Human Resource Management Academic Research Society (www.hrmars.com)

This article is published under the Creative Commons Attribution (CC BY 4.0) license. Anyone may reproduce, distribute, translate and create derivative works of this article (for both commercial and non-commercial purposes), subject to full attribution to the original publication and authors. The full terms of this license may be seen

at: http://creativecommons.org/licences/by/4.0/legalcode

\section{Vol. 8, No. 12, 2018, Pg. 2195 - 2206}

Full Terms \& Conditions of access and use can be found at http://hrmars.com/index.php/pages/detail/publication-ethics 


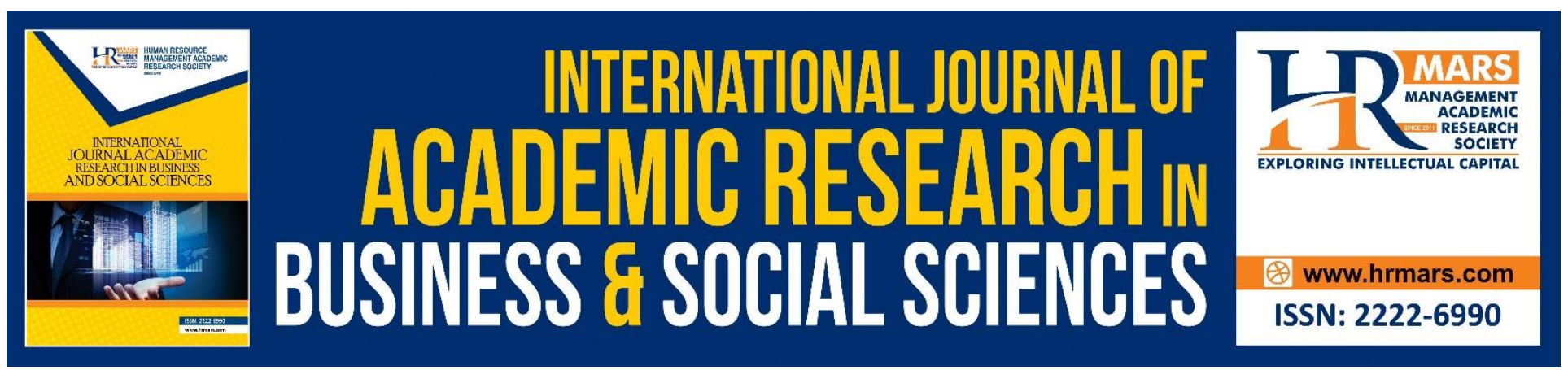

\title{
Coggle: SWOT Analysis in Lifelong Learning Education Using Online Collaborative Mind-Mapping
}

\author{
Nurul Aisyah Kamrozzaman, Jamaludin Badusah, Wan Muna \\ Ruzanna Wan Mohammad \\ Faculty of Education, National University of Malaysia, Bangi, Selangor, Malaysia \\ Email:nurulaisyahkamrozzaman@gmail.com,jhb@ukm.edu.my,munaruzanna@ukm.edu.my
}

\begin{abstract}
Presently, lifelong learning culture has become a phenomenon in education for sustainable development. In fact, lifelong education offers the society a second chance in changing the standard of living. Therefore, this study is conducted to determine the strengths, weaknesses, opportunities and adversities to a lifelong learning programme. This study adopts Online Collaborative MindMapping, Coggle as a data collection and analysis tool applying qualitative approaches. A total of 239 research participants consisting of executive postgraduate students from the Faculty of Education, Universiti Kebangsaan Malaysia were recruited. The analysis used to obtain the findings is based on SWOT analysis which consisted of techniques used to identify the strengths, advantages, opportunities and threats that exist in this lifetime education program. Findings in this research found that technology, systematic management and experienced instructors contribute to the strengths of the programme, whereas broadband access issues, inconducive classrooms and pedagogical problems result in its weaknesses. Furthermore, findings on difficulties to this lifelong learning programme show students acquire external limitations such as time constraints and personal factors. However, this programme provides opportunities and advantages to all the students as it is conducted during school holidays. Hence, this study suggests that future research will develop a suitable module and approach for lifelong learning students.
\end{abstract}

Keywords: SWOT Analysis, Lifelong learning, Coggle, Online Collaborative Mind Mapping, Higher Education

Introduction

UNESCO defines lifelong education as one of the key aspects in achieving global sustainable development. This is emphasised in the Sustainable Development Goals (SDG) policy where the fourth goal is to focus on delivering quality inclusive education and providing access to lifelong learning for all parties (UNESCO 2015). Education also offers the freedom to pursue knowledge diversity that provides the potential for increased capabilities and abilities (World Bank 2018). 
INTERNATIONAL JOURNAL OF ACADEMIC RESEARCH IN BUSINESS AND SOCIAL SCIENCES Vol. 8, No. 12, Dec, 2018, E-ISSN: 2222-6990 C 2018 HRMARS

At the Southeast Asian region level, upgrade of lifelong education and learning has also been recognised as an important element in sustainable development for various sectors, including the employment, youth, and rural development sectors (ILO 2016; Anon 2017; Yoruzu 2017).

The region has several education policies that are focused on formal education including primary, secondary and tertiary education, namely the ASEAN Socio-Cultural Community Blueprint 2025 and SEAMEO Southeast Asian Education Agenda 7 Priority Action Areas (2015-2035). However, while the policies emphasise on access to quality education for all, they have little emphasis on adult education (Yoruzu 2017). Today, citizens who are knowledgeable in a country are crucial as this is a form of response to contemporary political, economic and social challenges (Mosweunyane and Molosi-France 2017). For example, similar to the state of Mauritius, the policy that is developed to assist lifelong education is the key goal of making the country a knowledge hub in the field of lifelong learning in the year 2020 (Education and Human Resources 2008-2020, 2009). As a result, there are also several policies from other countries that are developed to assist lifelong education to continue to be recognised.

Table 1 Summary of Lifelong Learning Policy Based on Several Countries

\begin{tabular}{|c|c|c|}
\hline Country & Policies & Goal / Vision in Policy \\
\hline Mauritius & $\begin{array}{l}\text { Education and human } \\
\text { resources strategy plan } \\
\text { 2008-2020. (Ministry of Education, } \\
\text { Culture \& Human Resources 2009) }\end{array}$ & $\begin{array}{l}\text { Mauritius is the knowledge hub in the region and } \\
\text { becomes a centre for excellence in higher } \\
\text { education by } 2020\end{array}$ \\
\hline Cyprus & $\begin{array}{l}\text { National lifelong learning } \\
\text { strategy 2014-2020 . (Directorate } \\
\text { General for European Programmes } \\
\text { 2014) }\end{array}$ & $\begin{array}{l}\text { In determining the strategies of all types of } \\
\text { education (formal, informal, informal), it is } \\
\text { necessary to emphasise on these three aspects: } \\
\text { - recognition of lifelong learning } \\
\text { - promoting lifelong learning research } \\
\text { - promoting integration / reintegration into } \\
\text { the labour market }\end{array}$ \\
\hline China & $\begin{array}{l}\text { National Plan for Medium- and Long- } \\
\text { Term Education Reform and } \\
\text { Development: } 2020 \text { (Ministry of } \\
\text { Education of the People's Republic of } \\
\text { China 2010) }\end{array}$ & $\begin{array}{l}\text { Develop and provide an open platform for modern } \\
\text { distance education }\end{array}$ \\
\hline \multirow[t]{4}{*}{$\begin{array}{l}\text { Republic of } \\
\text { Korea }\end{array}$} & $\begin{array}{l}\text { Lifelong Education Act (Act } \\
\text { No. 9641, May 8, 2009) }\end{array}$ & Article 4 (Ideal Lifelong Education): \\
\hline & & $\begin{array}{l}\text { - All citizens will be guaranteed equal } \\
\text { opportunities for lifelong education } \\
\text { Lifelong education should be implemented } \\
\text { based on volunteer participation and } \\
\text { voluntary studies }\end{array}$ \\
\hline & & $\begin{array}{l}\text { - Lifelong education will not be exploited as a } \\
\text { tool for political or personal propaganda }\end{array}$ \\
\hline & & $\begin{array}{l}\text { - Citizens who have completed lifelong } \\
\text { education courses will be rewarded with } \\
\text { sufficient social rewards, such as relevant } \\
\text { qualification accreditation }\end{array}$ \\
\hline Denmark & $\begin{array}{l}\text { Denmark's strategy for } \\
\text { lifelong learning: education }\end{array}$ & $\begin{array}{l}\text { Improve the value of lifelong learning by } \\
\text { strengthening the relationship between adult }\end{array}$ \\
\hline
\end{tabular}


INTERNATIONAL JOURNAL OF ACADEMIC RESEARCH IN BUSINESS AND SOCIAL SCIENCES Vol. 8, No. 12, Dec, 2018, E-ISSN: 2222-6990 C 2018 HRMARS

\begin{tabular}{|c|c|c|}
\hline & $\begin{array}{l}\text { and lifelong skills upgrading } \\
\text { for all (Danish Ministry of Education } \\
\text { 2007) }\end{array}$ & $\begin{array}{l}\text { education through adult learning communities } \\
\text { learning in formal education systems and at work. }\end{array}$ \\
\hline Vietnam & $\begin{array}{l}\text { Education law. National } \\
\text { Assembly of the Socialist } \\
\text { Republic of Viet Nam. 11th } \\
\text { legislature, 7th session, 5th } \\
\text { May to 14th June, } 2005 . \\
\text { Hanoi, 2005. [National Assembly of } \\
\text { the Socialist Republic of Vietnam } \\
\text { 2005] }\end{array}$ & $\begin{array}{l}\text { Continuous education should encourage students' } \\
\text { initiatives and experiences according to relevant } \\
\text { interests for the development of their own } \\
\text { capabilities by using modern facilities and } \\
\text { information technology to enhance the quality of } \\
\text { teaching and learning competencies. }\end{array}$ \\
\hline Thailand & $\begin{array}{l}\text { The national Education Act, year } \\
1999 \text { (Office of the National } \\
\text { Education Commission 1999) }\end{array}$ & $\begin{array}{l}\text { Education Act shall be based on the following } \\
\text { principles: } \\
\text { - Lifelong education for all. } \\
\text { - All levels of society need to be involved in } \\
\text { the provision of education. } \\
\text { - Continuous development to improve } \\
\text { knowledge and learning processes. }\end{array}$ \\
\hline Brunei & $\begin{array}{l}\text { National Education Strategic Plan } \\
\text { 2012-2017 (Ministry of Education } \\
\text { 2012) }\end{array}$ & $\begin{array}{l}\text { Lifelong learning programmes are able to provide } \\
\text { access and opportunities in creating experts in the } \\
\text { industry and first-class trading. }\end{array}$ \\
\hline
\end{tabular}

\section{Lifelong Learning (LLL) In Malaysia}

In Malaysia, a plan has been formulated to enhance lifelong learning to shape Malaysians in pursuing civilisation and increasing the quality of life. This is the result of LLL that is able to produce output to mobilise the community's talents to the maximum level. Due to these factors, Blueprint Enculturation of Lifelong Learning for Malaysia 2011-2020 was inaugurated in 2011 which outlines the direction, objectives and strategies in implementing LLL. This plan is targeting the year 2020 and is a compulsory learning requirement in education at the school and tertiary level.

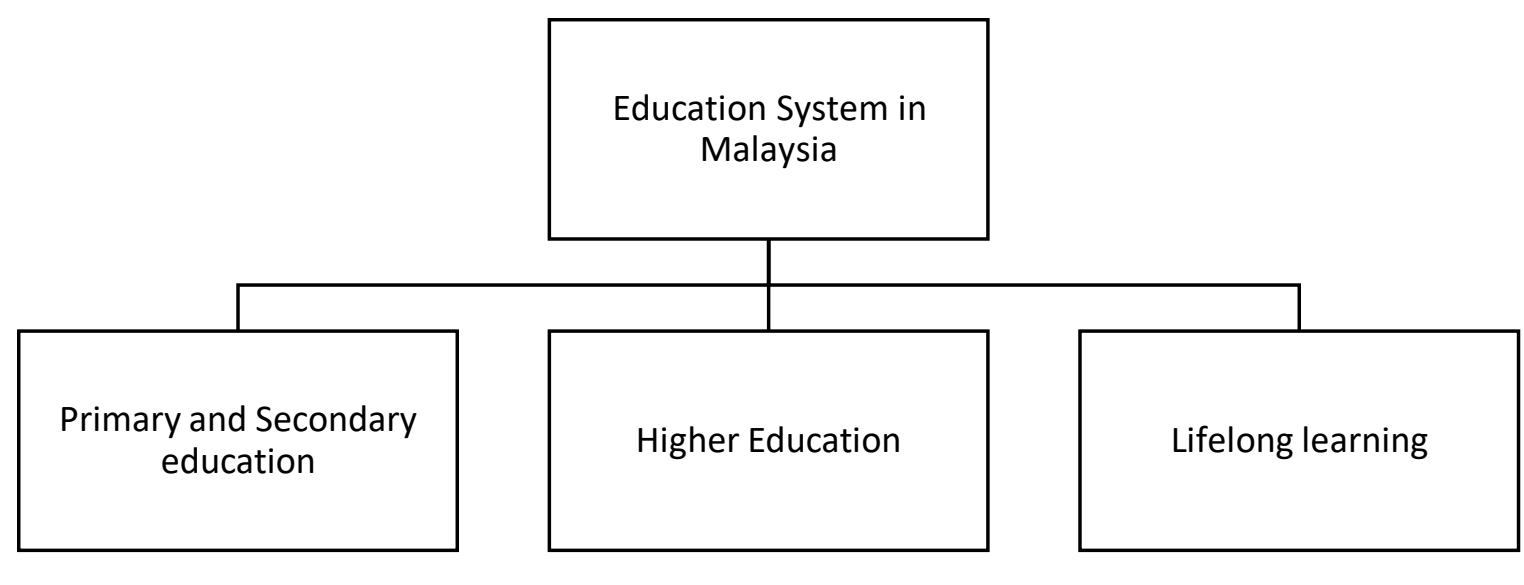

Figure 1 Central Flow of Education System in Malaysia in 2020 Source: Blueprint Enculturation of Lifelong Learning for Malaysia 2011-2020.

To achieve this plan, four strategies have been formulated to shape the sustainability of LLL. The four strategies are: (i) Upgrade Mechanism and Infrastructure, (ii) Enhance Public Awareness and 
INTERNATIONAL JOURNAL OF ACADEMIC RESEARCH IN BUSINESS AND SOCIAL SCIENCES

Vol. 8, No. 12, Dec, 2018, E-ISSN: 2222-6990 @ 2018 HRMARS

Participation in Lifelong Learning (iii) Ensure Continuity and Appreciation of Lifelong Learning, and (iv) Provide Financial Support for Lifelong Learning.

(i) Upgrade Mechanism and Infrastructure

- National Lifelong Learning Committee (NLC)

- Flexi Lifelong Learning for All

- Institutional Transformation Programme

- Research \& Development for Innovation (ReaDI) in Lifelong Learning

- Productivity Gain Programme (PGP)

- Lifelong learning-on-track

(ii) Enhance Public Awareness and Participation in Lifelong Learning

- "Lifelong Learning for Everyone"

- "Lifelong Learning is Everywhere"

- "My Lifelong Learning" (My3L)

- "Hop-on-the-Lifelong Learning-Train"

(iii) Ensure Continuity and Appreciation of Lifelong Learning

- Quality Assurance and Recognition Centre (L-QARC)

- National Centre for Apel (NCAPEL)

- Credit Bank System (CBS)

- Malaysian Online Lifelong Learning Framework (MOLF)

(iv) Provide Financial Support for Lifelong Learning

- National Lifelong Learning Funding Mechanism

- Lifelong Learning Funding Initiatives

- Lifelong Learning Award of Excellence

- Additional Lifelong Learning Tax Incentives

- Lifelong Learning Loan Scheme

- Non-Governmental Lifelong Learning Fund (MyLLL Grant)

- Strategies, Performance and Accountability Metrics, Targets and Sponsoring Organisations

At present, the master plan that has been built is currently in the implementation phase (2016-2020) in which this phase is focused on enhancing the private sector involvement in LLL and provide adequate financial facilities to promote LLL culture among Malaysians. In line with the plan, the Ministry of Higher Education has formulated the 2015-2025 Education Blueprint (High Education) Malaysia by highlighting lifelong learning in tertiary education. 


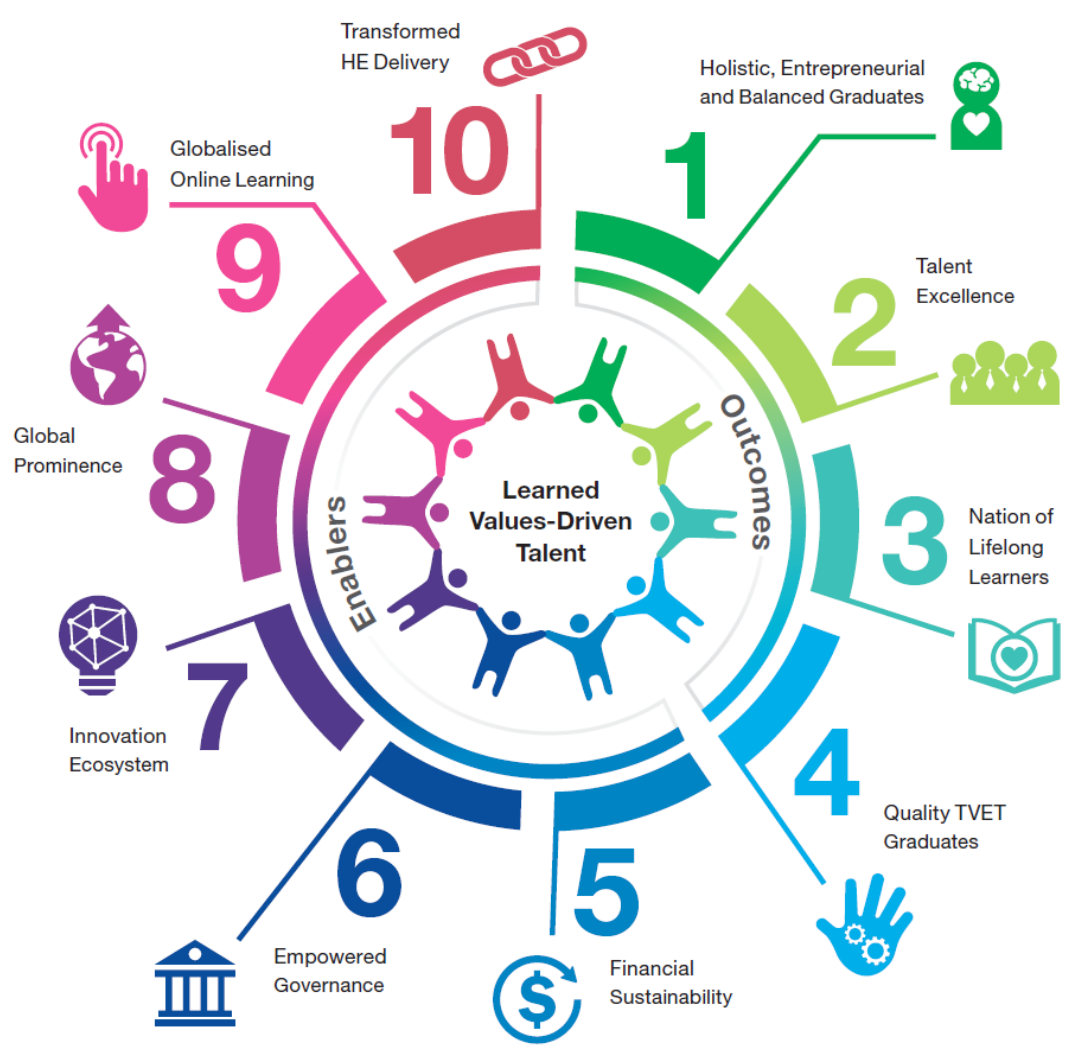

Figure 2 Malaysia Education Blueprint 2015-2025 (Higher Education)

Support from the Blueprint Enculturation of Lifelong Learning for Malaysia 2011-2020, PPPM (PT) 2015-2025 has outlined ten waves to achieve student aspirations that will drive their productivity as holistic graduates which includes to acknowledge life-long learning.

At the third wave, the ministry has set up several strategies to support the LLL master plan where adults have access to effective and sustainable education. This third wave is divided into two parts including APEL (Accreditation of Prior Experiential Learning) and lifelong learning. APEL stands for Accreditation of Prior Experiential Learning where this education path has been prepared within the Malaysian qualification framework for individuals to develop themselves and to award graduates recognition certificates based on qualification level. APEL is an alternative entry point for individuals who are unable to enter the university for any reason or have no academic qualification but can still fulfill the requirements to pursue to a higher level of education through the recognised accumulated experience and knowledge to extend to higher levels (Bahril and Wahid 2011). The Malaysian Qualifications Agency or MQA has been tasked in ensuring that APEL is implemented according to the recommended requirements.

Lifelong learning is one of the government's initiatives in providing individuals with the opportunity to revamp their knowledge in accordance with the requirements as per requested by employers either through formal or informal methods. The LLL is an extension of the 2011-2020 Lifelong Learning Action Plan by encouraging working individuals to obtain academic qualifications regardless of age limits and are able to contribute to the country's economic development. At 
present, Higher Educational Institutions (HEIs) have provided various opportunities such as offering programs or courses to attain formal qualifications in order to get to higher levels. Among them are UTM Space, Sarjana Eksekutif UKM, UMCCED, and Pace UUM. Opportunities offered are mainly through distance learning, e-learning, on-the-job learning or part-time learning to provide convenience and enhancement to the number of candidates in obtaining formal qualifications. In addition, the KPT also targets 2025 as the year where LLL becomes a high-quality people's culture and lifestyle through the three key strategies that have been developed.

\section{Problem Statement}

Lifelong education has long been introduced, but the programs that are still underway need to be improved (Jamaludin et al. 2017). Gagunskii et al. (2016) also states that lifelong education needs to be made in line with the changing needs of the economy. This is because adults are contributing to the development of the national community (UNESCO 2015). Previous studies have found that formal lifelong learning that has been implemented had issues in the context of adulthood (Yang et al. 2015; Yoruzu 2017). The scenario can be seen in Malaysia where the context of lifelong learning is not a continuous process (Prashanti et al. 2017). This is due to several factors such as time constraint, difficulty in accessing materials, and consequently will result in lower student motivation (Yoruzu 2017, Norshakirah and Norizzati 2017, Norazah et al. 2017). Therefore, this study aims to evaluate the students' needs in the educational lifelong learning through SWOT analysis to further improve the life-long education program.

\section{Coggle as Online Collaborative Mind-Mapping}

Coggle is a collaborative online mind map that is used to create ideas, integrate information, or plan assignments. The term "mind map" was developed by Tony Buzan's idea in around 1960 where it is a tool to help improve memory and generate ideas (Ralston and Cook 2007). In addition, it is also very popular among students especially in helping to remember, understand and connect with other users (Ang et al. 2010). This mind map can be initiated in real-time, which means that it can be used anywhere in different environments and is able to obtain timely information with the learning community. Additionally, Coggle allows for integration of images and links via its map branches and also has a revision history feature, in which users can go back to a specific version of the mind-map based on the time changes were made and revert to the original version of the mind-map (Helmi et al. 2017). Lin et al. (2017) states that the collaborative effectiveness of mind map can be implemented with Bandura Learning Theory and Vygotsky, where human beings are able to construct ideas through observation of others. Jamaludin et al. (2017) in their study also use Coggle as a data-gathering tool for qualitative data. This is because Coggle is able to collect large scale data. Aside from that, a study by Thorpe (2008) expresses that by using the mind map, a person's knowledge will increase exponentially, especially in terms of one's memory, comprehension in what the person wants to do, ability to work as a team member, and help to develop problem solving skills. 
INTERNATIONAL JOURNAL OF ACADEMIC RESEARCH IN BUSINESS AND SOCIAL SCIENCES

Vol. 8, No. 12, Dec, 2018, E-ISSN: 2222-6990 C 2018 HRMARS

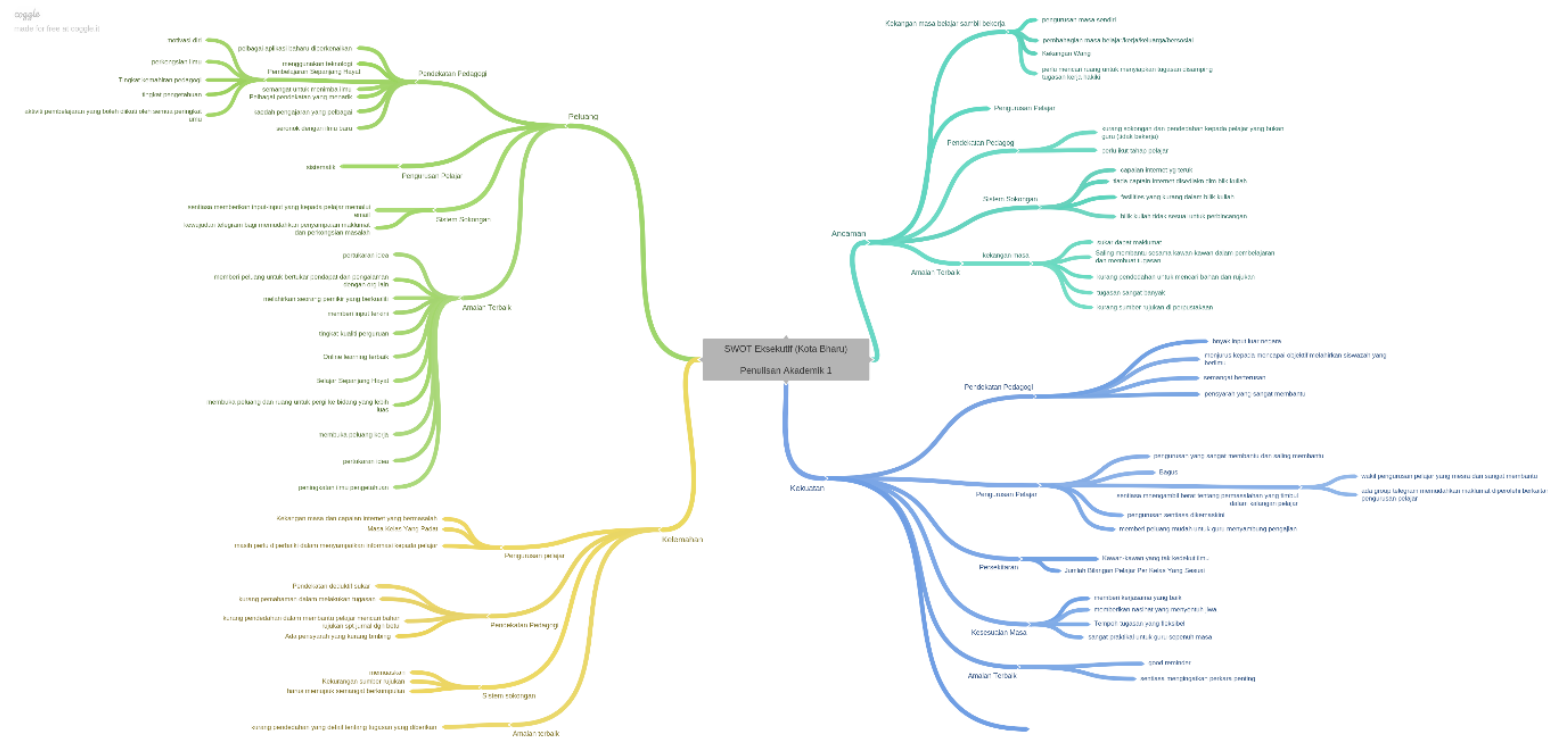

Figure 3: Example of Coggle as an Online Collaborative Mind-Mapping

\section{Participants}

Participants in the study consisted of 239 students who attended the executive postgraduate program in the faculty of education, Universiti Kebangsaan Malaysia. This executive postgraduate program is a lifelong education program that has been conducted during school holidays. Four learning centers are open to students to facilitate learning in Selangor, Sarawak, Kelantan and Sabah. The program also offers 20 courses of Bachelor's Degree in Education to students, namely Curriculum and Pedagogy, Malay Language Education, Islamic Education, TESL, Mathematics Education, Computer Education, Science Education, Business Studies and Entrepreneurship Education, Measurement and Evaluation, Sports Management, Educational Administration, Educational Psychology, Social Psychology in Education, Educational Sociology, Arabic Language Education, Economics Education, Literature Education, History Education, Guidance and Counseling, and Special Education.

\section{Method of the Study}

This study uses Coggle in obtaining the findings of the study. Coggle has been divided into four parts, namely strength, advantage, opportunity, and threat. Upon completion of the semester, students will need to assess the four aspects using Coggle. These four aspects are SWOT methods in identifying the strengths, advantages, opportunities, and threats that exist in lifelong education programs. SWOT is a strategic, best, systematic and environmentally friendly internal and external analysis method that can be used to further develop new strategies that can be used to improve performance (Kay Dora 2010). 
INTERNATIONAL JOURNAL OF ACADEMIC RESEARCH IN BUSINESS AND SOCIAL SCIENCES

Vol. 8, No. 12, Dec, 2018, E-ISSN: 2222-6990 C 2018 HRMARS

\section{Result and Discussion}

The findings from Coggle were analyzed using SWOT analysis.

\section{STRENGTHS}

Based on the findings of the study, the strengths in the life-long education program have three themes, namely systematic management, experienced instructors and diverse technology in learning. Facilities provided such as accommodation, fee payment facilities and all the problems faced by students are quickly resolved by the administrators. Seamless management of the program facilitates students to focus on learning without facing external factors.

Additionally, the provision of experienced instructors also helps to increase student confidence in the executive postgraduate program. In this lifelong education program, all teaching staff have a doctorate level in education and have decent research publications. Hence, the provision of credential trainers increases students' confidence in the program.

The diversity of technology in classroom learning is also considered as the strength in the program. The findings show that the use of learning methods such as Kahoot, Coggle and Padlet greatly helps to motivate students to continue learning.

\section{WEAKNESS}

One of the disadvantages of the lifelong education program is that the students are experiencing internet access issues. The crucial problem with poor Wi-Fi facilities has caused classroom learning to be problematic. Furthermore, most students have expressed that the classrooms are not suitable for lifelong education program as they are not conducive. The findings also revealed that the density of a class affects in lesser opportunities to ask questions. In this program, each class contains 40 students, especially in compulsory course classes. Therefore, due to the classroom density, student's interaction with trainers were recorded to be minimal.

In addition, the study also found that there was a problem with pedagogical approaches in the classroom. Due to the age difference, most students need instructors who can assist them with the appropriate approach. Therefore, the diversity of pedagogical methods needs to be applied in the classroom so that all student levels can achieve equality in learning.

\section{OPPORTUNITIES}

The opportunities reported by participants in lifelong education programs are that the students are able to use technology diversity in the classroom, in which they can be re-applied when these students return to work, especially in schools. In addition, the offered program provides an open opportunity for students who work to continue their studies. For students who face time constraints and service factors in the rural areas of Sarawak, this degree program has benefited them greatly in enhancing their field of opportunity and knowledge. This is because lifelong education programs are offered during school holidays. Therefore, time constraints from teacher-students can be avoided.

\section{THREATS}

The overall findings suggested that students found threats from the program in which they are consisted of three themes; factors in infrastructure facilities, factors in teaching staff, and personal 
INTERNATIONAL JOURNAL OF ACADEMIC RESEARCH IN BUSINESS AND SOCIAL SCIENCES Vol. 8, No. 12, Dec, 2018, E-ISSN: 2222-6990 @ 2018 HRMARS

factors. In terms of infrastructure facilities, the facilities provided in some learning centers are quite silent and room conditions are obsolete and difficult to get food. This poses a threat to students staying in the space provided. On top of that, the next threat is that of personal factors such as student's time division, financial threats, and lack of support from employers. The threat faced by these students can help researchers to improve existing programs to be more interactive and friendly for lifelong education.

\begin{tabular}{|c|c|}
\hline Strengths & Weakness \\
Systematic management & Wi-Fi facilities \\
Experienced instructors & Classes that are not conducive \\
Technological diversity & Pedagogical Approach \\
\hline Opportunities & Threats \\
Implementation of technology in & Infrastructure facilities \\
schools & Teaching factors \\
Lifelong education program & Personal factors \\
\hline
\end{tabular}

Figure 4: The SWOT Quadrant of the Lifelong Learning Program

\section{Conclusion}

In conclusion, the lifelong education program offered has a lot of strengths rather than weaknesses and threats. However, the weaknesses and threats in this program need to be remedied so that the program can be expanded to the rest of the country. In addressing the weakness of the approach, the instructors should apply other approaches such as the heutagogy approach. Blaschke (2018) states that the heutagogy approach is one of the most appropriate approaches nowadays as it gives the students the freedom to choose the preferred learning method. This heutagogy approach focuses on improving students' motivation in creating awareness, desire and commitment to achieve goals (Narayan 2014; Boyer et al. 2014; Hase 2016). By practicing this approach, the lifelong education can be carried out continuously. Apart from that, this lifelong program can also be carried out via online learning. For example, the Massive Open Online Courses (MOOC) offers a variety of online courses for this lifelong educational community so they can discuss with the learning community (Viswanathan 2012). Organizations like universities can also develop MOOC's own content for a lifelong education program course. Besides MOOC, there are also methods such as m-learning. MLearning is implemented with the application of mobile technology that provides learning in a seamless, ubiquitous, and context-aware manner that can be implemented anywhere and anytime. In the meantime, m-learning devices (e.g. iPad) can provide a lifelong learning that fits into the context of lifelong learners - in various contexts including those working, live in locations with poor internet access, and have weak technological literacy levels (Amin and Norazah 2013; Yeap et al. 2016). Therefore, constraints such as time management and instructional interactions of students in the classroom can be avoided. With online learning, students are able to talk anywhere and anytime. Additionally, lecturers can also apply online learning along with heutagogy approaches. Therefore, 
INTERNATIONAL JOURNAL OF ACADEMIC RESEARCH IN BUSINESS AND SOCIAL SCIENCES

Vol. 8, No. 12, Dec, 2018, E-ISSN: 2222-6990 @ 2018 HRMARS

for future studies, an appropriate module should be developed together with a heutagogy approach for lifelong learning students.

\section{References}

Blaschke, L. M. (2018). Self-determined Learning (Heutagogy) and Digital Media Creating Integrated Educational Environments for Developing Lifelong Learning Skills. In Kergel D., Heidkamp B., Telléus P., Rachwal T., Nowakowski S. (Eds.). The Digital Turn in Higher Education, pp. 129140. Switzerland: Springer.

Boyer, S. L., Edmondson, D. R., Artis, A. B., \& Fleming, D. 2014. Self-directed learning: A tool for lifelong learning. Journal of Marketing Education, 36(1): 20-32.

Danish Ministry of Education. (2007). Denmark's strategy for lifelong learning: education and lifelong skills upgrading for all. http://uil.unesco.org/i/doc/lifelong-learning/policies/denmarkdenmarks-strategy-for-lifelong-learning-education-and- lifelong-skills-upgrading-forall.pdf [28 September 2018].

Directorate General for European Programmes, Coordination and Development. (2014). National lifelong learning strategy 2014-2020. http://uil.unesco.org/document/cyprusnational-lifelong-learning-strategy-2020- issued-2014 [28 Septemper 2018].

Gogunskii, V., Kolesnikov, O., Kolesnikova, K., \& Lukianov, D. (2016). " Lifelong learning" is a new paradigm of personnel training in enterprises. Eastern-European Journal of Enterprise Technologies, 82(4/2), 4-10.

Hase, S. (2016). Self-Determined Learning (Heutagogy): Where Have We Come Since 2000? Southern Institute of Technology Journal of Applied Research (SITJAR) https://www.sit.ac.nz/SITJAR\#3101196-special-edition-heutagogy-or-self determinedlearning [5 Julai 2018]

Helmi Norman, Norazah Nordin, Melor Md Yunus, Fariza Md Sham, Mohamad Azlan, Shah Zaidi \& Mohamed Ally (2017). Online Collaborative Mind-mapping in Multidisciplinary Research Teams for Eliciting Bottom 40 Transdisciplinary Community Issues. Proceedings of the 2nd World Conference on Blended Learning (IABL2017). APRIL 26-28, 2017: 103-107.

ILO (International Labour Office). (2016). World Employment Social Outlook Trends 2016. Geneva.

Kay, D. (2010). Faktor Dalaman dan Luaran yang Kritikal Terhadap Perancangan Strategik Firma. Jurnal Intelek, Vol 5, No 1 http://jurnalintelek.uitm.edu.my/index.php/main/issue/view/1 [ 1 September 2018].

Kementerian Pendidikan Malaysia. (2015). Pelan Pembangunan Pendidikan Malaysia 2015-2025 (Pendidikan Tinggi). Kementerian Pendidikan Malaysia: Putrajaya.

Lin, Y. T., Chang, C. H., Hou, H. T., \& Wu, K. C. (2016). Exploring the effects of employing Google Docs in collaborative concept mapping on achievement, concept representation, and attitudes. Interactive Learning Environments, 24(7), 1552-1573.

Ministry of Education. (2003). Ministry of Education strategy 2015. Finland: Ministry of Education.

Ministry of Higher Education. (2011). Blueprint Enculturation of Lifelong Learning for Malaysia 20112020. Univision Press: Selangor. 
INTERNATIONAL JOURNAL OF ACADEMIC RESEARCH IN BUSINESS AND SOCIAL SCIENCES

Vol. 8, No. 12, Dec, 2018, E-ISSN: 2222-6990 @ 2018 HRMARS

Ministry of Education, Culture \& Human Resources. (2009). Education \& Human Resources

Strategy Pelan 2008 - 2020. http://uil.unesco.org/i/doc/lifelong-learning/policies/mauritiuseducation-and-human-resources-strategy-plan-2008-2020.pdf [28 September 2018].

Ministry of Education of the People's Republic of China. (2010). National Plan for Medium- and Long-

Term Education Reform and Development: 2020. http://uil.unesco.org/document/chinanational-plan-medium-and-long-term education-reform-and-development-2020-

issued-2010 [28 September 2018].

Ministry of Education. (2012). The Ministry of Education Strategic Plan 2012 - 2017. Brunei: Ministry of Education.

Mosweunyane, D., \& Molosi-France, K. (2017). Lifelong Learning for Sustainable Development in the Developing World. International Journal of Academic Research in Progressive Education and Development 2017, Vol. 6, No. 4 DOI: 10.6007/IJARPED/v6-i4/3072 URL: http://dx.doi.org/10.6007/IJARPED/v6-i4/3072 hlmn 1-12.

Narayanan, Y. And Herrington, J. (2014). Towards A Theoretical Mobile Heutagogy Framework. In: ASCILITE 2014 Rhetoric and Reality, Dunedin, New Zealand, 23 - 26 November.

http://researchrepository.murdoch.edu.au/id/eprint/26680/ [5 Oktober 2018].

National Assembly of the Socialist Republic of Vietnam. (2005). Education Law. Assembly of the Socialist Republic of Viet Nam. 11th legislature, 7th session, Hanoi 5 - 14 Jun 2005. http://uil.unesco.org/i/doc/lifelong-learning/policies/viet-nam-education-law-2005.pdf [28 September 2018].

Ralston, J., Cook, D. (2007). Collaboration, ICT and Mind Mapping. Reflecting Education. 3(1), 61-73.

Thorpe, M. (2008). Effective Online Interaction: Mapping Course Design to Bridge from Research To Practice. Australasian Journal of Educational Technology, 24(1) pp. 57-72.

UNESCO. (2015). Education for All 2015 National Review Report: Zimbabwe. Laporan telah dibentangkan di World Education Forum (Incheon, Republic of Korea, 19-22 May 2015. http://unesdoc.unesco.org/images/0023/002304/230412e.pdf [28 Septemper 2017].

UNESCO. (2015). Education 2030: Incheon Declaration and Framework for Action for the implementation of Sustainable Development Goal 4. UNESCO.

Viswanathan, R. (2012). Teaching and Learning through MOOC. Frontiers of Language and Teaching, $3(1), 32-40$.

World Bank. (2018). Learning to Realize Education's Promise. Washington: The World Bank.

Yang, J., Schneller, C., \& Roche, S. (2015). The Role of Higher Education in Promoting Lifelong Learning. Germany: UNESCO.

Yeap, J. A., Ramayah, T., \& Soto-Acosta, P. (2016). Factors propelling the adoption of m-learning among students in higher education. Electronic Markets, 26(4), 323-338.

Yoruzu, R. (2017). Lifelong learning in transformation: Promising practices in Southeast Asia. Germany: UNESCO. 